\title{
The Effect of Soaking Time of Liquid Smoke on the Quality and Storability of Cow Meat
}

\author{
U Purba, I Sembiring, E Mirwandhono, N Ginting, I Sembiring \\ Animal production program study, faculty of agriculture, universitas sumatera utara, \\ Medan 20155 \\ e-mail : nurzainahginting@gmail.com
}

\begin{abstract}
Post harvest quality of cow meat and in storage may changes as consequence of biochemistry and microbiology process. This changes make meat durability and processed products will be limited. So that necessary processing to improve meat durability is needed. This study aimed to test the effect of soaking time of liquid smoke against meat durability meet by tenderness and organoleptic test(texture, aroma, flavor and tenderness). This research was conducted at Laboratory of Food Technology Faculty of Agriculture, University of North Sumatra from Mei to June 2016.The design used in this study was completely randomized factorial design (factorial CRD) using two factors:the soaking time of liquid smoke(A): (5 minutes, 10 minutes and15minutes) and storability(P): ( 1 week, 2 weeks, 3 weeks and 4 weeks). The parameters analyzed were cooking shrinkage, tenderness and organoleptic test(texture, aroma, and flavor).

The results showed that soaking time of liquid smoke gave highly significant effect $(\mathrm{P}<0,01)$ to the organoleptic test (aroma), while storability give highly significant effect $(\mathrm{P}<0,01)$ to the cooking shrinkage $(\%)$, tenderness, andorganoleptic test(texture, aroma, and flavor).The best results were obtained ats oaking time of liquid smoke 15 minutes.
\end{abstract}

\section{Introduction}

Liquid smoke is a binder which contains phenol compounds which are antioxidants, therefore liquid smoke can inhibit food damage by donating hydrogen and is effective in inhibiting fat autookyration, thereby reducing food damage due to oxygen oxidation. Phenol compounds found in liquid smoke can bind other groups such as aldehydes, ketones, and esters which can affect the binding capacity of the sample.

Meat that undergoes a post-gourd process will experience a decrease in the binding capacity of the water so that the cooking shrinkage will increase, so it is necessary to add ingredients that are binder. Natural food additives that are preservative as well as binding agents and safe for consumption by humans are liquid smoke, with the addition of liquid smoke to pascarigor meat, it is expected to increase the ability of meat to bind water and cook the shrinkage of meat is low. This is the background of the research on the addition of liquid smoke to meat as a binder in the type of muscle namely Semitendinosus, during post rigor in improving the physical and functional properties of meat which includes cooking shrinkage, tenderness, wetness, flavor, and masticatory residues. So that the quality of meat that will be made in a product can be improved. Muscle protein is closely related to meat water. Muscle proteins have hydrophilic properties, which interact with water to form hydrogen bonding bonds (binding molecular molecules of meat water). It has been stated that the binding capacity of water is one of the physical karecteistic variables of meat.

\section{Research Methods}

\subsection{Materials and Research Tools}

Materials and Research Materials The materials used are beef, liquid smoke, soy sauce, shallots, garlic and roiko.

The tools used in the study include a basin for placing meat, a measuring cup for measuring liquid smoke, a preciscio penetrometer for measuring meat tenderness, a stopwatch for measuring meat tenderness, a stove for cooking meat, a scale for measuring sample weight, label paper for marking each treatment, knives for 
cutting meat, sliced as a base for cutting meat, serving as cooking medium for meat, plastic stamp as a medium for soaking meat, polypropy plastic as a cover for meat on a plastic stamp.

\subsection{Research methods}

The experimental design carried out was a factorial completely randomized design with 12 combinations of 3 replications. The experimental design model is:Faktor pertama yaitu 3 level dosis asap cair yaitu:

$\mathrm{A}_{1} \quad$ : Soaking liquid smoke 5 minutes

$\mathrm{A}_{2} \quad$ : Soaking 10 minutes of liquid smoke

$\mathrm{A}_{3} \quad$ : Soaking 15 minutes of liquid smoke

1. The second factor is 4 levels of old storage, namely: $\mathrm{P}_{1}$ : Lama simpan 1 minggu

$$
\begin{array}{ll}
\mathrm{P}_{2} & : 2 \text { weeks } \\
\mathrm{P}_{3} & : 3 \text { weeks } \\
\mathrm{P}_{4} & : 4 \text { weeks }
\end{array}
$$

The mathematical model according to Hanafiah (2002) for the complete randomized trial design used is:

$\mathbf{Y}_{\mathrm{ijk}=\boldsymbol{\mu}}+\boldsymbol{\alpha}_{\mathrm{i}}+\boldsymbol{\beta} \mathbf{j}+(\boldsymbol{\alpha} \boldsymbol{\beta})_{\mathrm{ijj}}+\sum_{\mathrm{ijk}}$

Information:

$\mathbf{Y}_{\mathbf{i j k}} \quad$ : Observation value of the first level of factor A, tractor B, the level of $\mathbf{j}$ and k-test

$\boldsymbol{\mu} \quad:$ General average

$\boldsymbol{\alpha}_{\mathbf{i}} \quad$ : The main influence of the i-level factor

$\boldsymbol{\beta j} \quad$ : The main effect of the $\mathrm{j}$-level factor

$(\boldsymbol{\alpha} \boldsymbol{\beta})_{\mathrm{ij}} \quad$ : Effect of factor A level I and factor B level $\mathrm{j}$

$\sum_{\mathrm{ijk}} \quad$ : Normal spread random effects

\subsection{Research Parameters}

Cook Shrinkage $(\%)$

The samples were weighed $(3 \mathrm{~g})$ then cut into a rectangle with a size of $1.5 \times 1.5 \times 1.5 \mathrm{~cm}$ then immersed in liquid smoke with $\mathrm{pH} 2.633$ with a prescribed soaking time. The sample is cooked for 2 hours. Samples that have been boiled are weighed. According to Soeparno (1992) the value of cooking losses can be calculated by the formula:

Cook Shrinkage $(\%)=($ BSS-BSSM $) \times 100 \% \quad$ BSS

Information:

BSS (fresh sample weight)

BSSM (sample weight after cooking)

Tenderness

Measurements of tenderness were carried out objectively using a precisio penetrometer. Samples that have been boiled are cut into rectangles with a thickness of $4 \mathrm{~cm}$. each sample was measured by stabbing at five points using a precio penetrometer which was pressurized at $100 \mathrm{~g}$ with a scale of $1 / 10 \mathrm{~mm}$ for 10 seconds. Meat tenderness values can be read on the scale indicated by the needle instructions and then the values are averaged (Sitorus, 2001). Tenderness values are assessed by the formula:

Tenderness $=$

$$
250
$$

$$
(\mathrm{x} 1+\mathrm{x} 2+\mathrm{x} 3+\mathrm{x} 4+\mathrm{x} 5) / 5
$$

$1 / 10$

\section{Assessment Organoleptic}

It is the result of testing of texture, aroma, taste and tenderness aided by 10 panelists. This scale is shown for all four criteria from 1-5.

Texture Organoleptic

Texture organoleptic tests were determined by the Soekarto method (2008). Determination of organoleptic values of texture was carried out by texture score test and hedonic texture. Samples that have been randomly marked by 10 panelists. Tests carried out with sensory (organoleptic) are determined based on a numerical scale. 


\section{Organoleptic Aroma}

The organoleptic aroma test was determined by the Soekarto method (2008). Determination of organoleptic value of aroma is done by testing the aroma scale and hedonic aroma. Samples that have been randomly marked by 10 panelists. Tests carried out with sensory (organoleptic) are determined based on a numerical scale.

\section{Flavor Organoleptic}

The taste organoleptic test was determined by the Soekarto method (2008). Determination of organoleptic value of taste was carried out by taste score test and hedonic taste. Samples that have been randomly marked by 10 panelists. Tests carried out with sensory (organoleptic) are determined based on a numerical scale.

\section{Research procedure}

Beef thigh meat is weighed and cut into a rectangular shape $1.5 \times 1.5 \times 1.5 \mathrm{~cm}$ with a thickness of 3 $\mathrm{cm}$. then the meat is soaked with liquid smoke with 5 minutes, 10 minutes and 15 minutes then the meat is heated for 6 hours then cooled for 5 minutes and stored at room temperature for 1 week, 2 weeks, 3 weeks and 4 weeks then cooked for 30 minutes then cooled. After that, the cooking shrinkage, tenderness and retrieval of organoleptic value data (texture, aroma, taste and tenderness) by panelists were 10 people.

\section{Results and Discussion}

\subsection{Cook Shrink (\%)}

Table 4 - 6 shows that the storability of beef has a very significant effect $(\mathrm{P}<0.01)$ on the cooking shrinkage of beef. The highest average was found in treatment P4 which was $10.02 \%$ and the lowest was found in treatment P1 which was 3.35\%. This is also consistent with the statement of Anonima (2010) which states that liquid smoke functions as a preservative.

Table 1. Effect of liquid smoke immersion doses and storage on cooking losses (\%) of beef

\begin{tabular}{|c|c|c|c|c|c|}
\hline \multirow{2}{*}{ Treatment } & \multicolumn{3}{|c|}{ Deuteronomy } & \multirow{2}{*}{ Total } & \multirow{2}{*}{ average } \\
\hline & 1 & 2 & 3 & & \\
\hline $\mathrm{A}_{1} \mathrm{P}_{1}$ & 10,00 & 10,00 & 10,00 & 30,00 & 10,00 \\
\hline $\mathrm{A}_{1} \mathrm{P}_{2}$ & 25,00 & 32,50 & 10,00 & 67,50 & 22,50 \\
\hline $\mathrm{A}_{1} \mathrm{P}_{3}$ & 10,00 & 6,67 & 6,67 & 23,34 & 7,78 \\
\hline $\mathrm{A}_{1} \mathrm{P}_{4}$ & 15,00 & 15,00 & 15,00 & 45,00 & 15,00 \\
\hline $\mathrm{A}_{2} \mathrm{P}_{1}$ & 6,67 & 25,00 & 6,67 & 38,34 & 12,78 \\
\hline $\mathrm{A}_{2} \mathrm{P}_{2}$ & 10,00 & 6,67 & 12,50 & 29,17 & 9,72 \\
\hline $\mathrm{A}_{2} \mathrm{P}_{3}$ & 33,33 & 10,00 & 10,00 & 53,33 & 17,78 \\
\hline $\mathrm{A}_{2} \mathrm{P}_{4}$ & 10,00 & 15,00 & 10,00 & 35,00 & 11,67 \\
\hline $\mathrm{A}_{3} \mathrm{P}_{1}$ & 15,00 & 7,50 & 6,67 & 29,17 & 9,72 \\
\hline $\mathrm{A}_{3} \mathrm{P}_{2}$ & 7,50 & 10,00 & 10,00 & 27,50 & 9,17 \\
\hline $\mathrm{A}_{3} \mathrm{P}_{3}$ & 6,67 & 15,00 & 10,00 & 31,67 & 10,56 \\
\hline $\mathrm{A}_{3} \mathrm{P}_{4}$ & 15,00 & 10,00 & 15,00 & 40,00 & 13,33 \\
\hline
\end{tabular}

Description: Different letters in the mean value show very significant differences $(\mathrm{P}<0.01)$.

In table 1, it can be seen that various treatments provide different number notations which mean that various treatments have a very significant effect $(\mathrm{P}<0.01)$ on cooking shrinkage values and treatment $\mathrm{P} 4$ has a very significant effect on treatments $\mathrm{P} 1, \mathrm{P} 2$ and $\mathrm{P} 3$.

\subsection{Tenderness ( $\mathrm{mm} / 10$ seconds / $250 \mathrm{~g}$ )}

Table 3 shows that the storage power has a very significant $(\mathrm{P}<0.01)$ effect on beef tenderness. The highest average was found in treatment P1 which was 86.95 and the lowest was found in treatment P4 which was 63.67 with a difference of up to $26.77 \%$. This difference is caused by enzyme activity and soaking time so 
that the enzyme can work longer in treatment P1 in the process of hydrolyzing the protein complex bound to the woven binder of the beef.

Table 2. Effect of liquid smoke immersion doses and storage power on tenderness of beef ( $\mathrm{mm} / 10$ seconds / $250 \mathrm{~g})$

\begin{tabular}{|c|c|c|c|c|c|}
\hline \multirow{2}{*}{ Treatment } & \multicolumn{3}{|c|}{ Deuteronomy } & \multirow{2}{*}{ Total } & \multirow{2}{*}{ average } \\
\hline & 1 & 2 & 3 & & \\
\hline $\mathrm{A}_{1} \mathrm{P}_{1}$ & 78,13 & 65,79 & 58,69 & 202,60 & 67,53 \\
\hline $\mathrm{A}_{1} \mathrm{P}_{2}$ & 63,45 & 49,41 & 60,68 & 173,54 & 57,85 \\
\hline $\mathrm{A}_{1} \mathrm{P}_{3}$ & 57,34 & 64,10 & 64,77 & 186,21 & 62,07 \\
\hline $\mathrm{A}_{1} \mathrm{P}_{4}$ & 44,64 & 58,69 & 50,00 & 153,33 & 51,11 \\
\hline $\mathrm{A}_{2} \mathrm{P}_{1}$ & 79,11 & 76,22 & 73,53 & 228,86 & 76,29 \\
\hline $\mathrm{A}_{2} \mathrm{P}_{2}$ & 60,39 & 78,13 & 80,13 & 218,64 & 72,88 \\
\hline $\mathrm{A}_{2} \mathrm{P}_{3}$ & 56,56 & 66,14 & 61,27 & 183,97 & 61,32 \\
\hline $\mathrm{A}_{2} \mathrm{P}_{4}$ & 51,87 & 65,10 & 61,88 & 178,85 & 59,62 \\
\hline $\mathrm{A}_{3} \mathrm{P}_{1}$ & 64,10 & 70,62 & 62,50 & 197,22 & 65,74 \\
\hline $\mathrm{A}_{3} \mathrm{P}_{2}$ & 73,53 & 59,24 & 60,68 & 193,45 & 64,48 \\
\hline $\mathrm{A}_{3} \mathrm{P}_{3}$ & 50,20 & 51,02 & 49,02 & 150,24 & 50,08 \\
\hline $\mathrm{A}_{3} \mathrm{P}_{4}$ & 55,31 & 56,05 & 46,30 & 157,66 & 52,55 \\
\hline
\end{tabular}

Description: Different letters in the mean value show very significant differences $(\mathrm{P}<0.01)$.

The storability of beef in a 1 week storage efficiency was not significantly different with a shelf life of 2 weeks but was significantly different with a shelf life of 3 and 4 weeks. This shows that the difference in the length of immersion time does not significantly affect the tenderness of beef but the effect can be seen in its shelf life.

This provides an answer that the soaking time of beef with liquid smoke is able to maintain the storability of beef to save 3 weeks.

\subsection{Organoleptic Texture}

Organoleptic texture assessment refers to the texture produced by meat when chewed. This texture is related to muscle muscle fibers which provide stimulation to the mouth and tongue. Table 10-12 shows that the storability of beef has a very significant effect $(\mathrm{P}<0.01)$ on the organoleptic value of beef texture.

Table 3. Effect of liquid smoke immersion doses and storage power on organoleptic values of beef texture

\begin{tabular}{|c|c|c|c|c|c|}
\hline \multirow{2}{*}{ Treatment } & \multicolumn{3}{|c|}{ Deuteronomy } & \multirow{2}{*}{ Total } & \multirow{2}{*}{ average } \\
\hline & 1 & 2 & 3 & & \\
\hline $\mathrm{A}_{1} \mathrm{P}_{1}$ & 3,80 & 3,40 & 3,50 & 10,70 & 3,57 \\
\hline $\mathrm{A}_{1} \mathrm{P}_{2}$ & 3,80 & 3,20 & 3,20 & 10,20 & 3,40 \\
\hline $\mathrm{A}_{1} \mathrm{P}_{3}$ & 3,40 & 3,00 & 3,00 & 9,40 & 3,13 \\
\hline $\mathrm{A}_{1} \mathrm{P}_{4}$ & 3,20 & 2,90 & 2,80 & 8,90 & 2,97 \\
\hline $\mathrm{A}_{2} \mathrm{P}_{1}$ & 3,60 & 3,80 & 3,40 & 10,80 & 3,60 \\
\hline $\mathrm{A}_{2} \mathrm{P}_{2}$ & 3,40 & 3,40 & 3,10 & 9,90 & 3,30 \\
\hline $\mathrm{A}_{2} \mathrm{P}_{3}$ & 3,30 & 3,10 & 2,90 & 9,30 & 3,10 \\
\hline $\mathrm{A}_{2} \mathrm{P}_{4}$ & 2,90 & 3,10 & 3,00 & 9,00 & 3,00 \\
\hline $\mathrm{A}_{3} \mathrm{P}_{1}$ & 3,70 & 3,60 & 3,60 & 10,90 & 3,63 \\
\hline $\mathrm{A}_{3} \mathrm{P}_{2}$ & 3,30 & 3,30 & 3,20 & 9,80 & 3,27 \\
\hline $\mathrm{A}_{3} \mathrm{P}_{3}$ & 3,20 & 3,00 & 2,60 & 8,80 & 2,93 \\
\hline $\mathrm{A}_{3} \mathrm{P}_{4}$ & 2,90 & 3,10 & 2,60 & 8,60 & 2,87 \\
\hline
\end{tabular}

Description: Different letters in the mean value show very significant differences $(\mathrm{P}<0.01)$. 
Table 3 shows that the highest organoleptic value of the texture was found in the treatment P1 ie 3.60 and the lowest in the treatment P4 was 2.94. P1 treatment was superior to $18.61 \%$ compared to P4. The P1 treatment was very significantly different from the other treatments, so it can be concluded that the storability of beef at storage 3 and 4 weeks gave a very significant effect on the organoleptic texture of beef.

\subsection{Aroma Organoleptic}

The average results of the influence of the duration of liquid smoke immersion and storing power on the organoleptic value of beef aroma can be seen in Table 3.

Table 3 shows that the duration of soaking of liquid smoke has a significant influence on the organoleptic value of the aroma of beef. The highest organoleptic value of aroma on A3 is 3.16 and the lowest is A1, which is 2.88 . The storability of meat has a very significant effect on the organoleptic value of beef aroma. The highest aroma organoleptic value was $\mathrm{P} 1$, which was 3.39 and the lowest was $\mathrm{P} 4$, which was 2.82 . The longer the soaking of beef in liquid smoke will produce the aroma of the most preferred panelists.

Based on this study, it can be answered that the longer the immersion of liquid smoke can increase the organoleptic value of the aroma of beef so that the shelf life is longer.

\subsection{Organoleptic Flavor}

The average results of the influence of the duration of soaking liquid smoke and storing power on the organoleptic value of beef flavor can be seen in Table 4 .

Table 4 Effect of liquid smoke immersion doses and storability on the value of organoleptic flavor of beef

\begin{tabular}{lrrrrr}
\hline \multirow{2}{*}{ Treatment } & \multicolumn{2}{c}{ Deuteronomy } & 3 & Total & average \\
\hline $\mathrm{A}_{1} \mathrm{P}_{1}$ & \multicolumn{2}{c}{2} & 3,30 & 10,30 & 3,43 \\
$\mathrm{~A}_{1} \mathrm{P}_{2}$ & 3,50 & 3,50 & 2,80 & 9,20 & 3,07 \\
$\mathrm{~A}_{1} \mathrm{P}_{3}$ & 3,10 & 3,30 & 3,00 & 8,90 & 2,97 \\
$\mathrm{~A}_{1} \mathrm{P}_{4}$ & 2,90 & 3,00 & 2,90 & 8,50 & 2,83 \\
$\mathrm{~A}_{2} \mathrm{P}_{1}$ & 2,80 & 2,80 & 3,40 & 9,50 & 3,17 \\
$\mathrm{~A}_{2} \mathrm{P}_{2}$ & 3,20 & 2,90 & 3,50 & 9,70 & 3,23 \\
$\mathrm{~A}_{2} \mathrm{P}_{3}$ & 3,20 & 3,00 & 3,10 & 8,70 & 2,90 \\
$\mathrm{~A}_{2} \mathrm{P}_{4}$ & 2,50 & 3,10 & 2,90 & 8,20 & 2,73 \\
$\mathrm{~A}_{3} \mathrm{P}_{1}$ & 2,60 & 3,70 & 3,80 & 10,40 & 3,47 \\
$\mathrm{~A}_{3} \mathrm{P}_{2}$ & 3,20 & 2,90 & 3,40 & 9,30 & 3,10 \\
$\mathrm{~A}_{3} \mathrm{P}_{3}$ & 3,00 & 3,00 & 2,90 & 8,70 & 2,90 \\
$\mathrm{~A}_{3} \mathrm{P}_{4}$ & 2,80 & 2,40 & 2,80 & 7,70 & 2,57 \\
\hline
\end{tabular}

Description: Different letters in the mean value show very significant differences $(\mathrm{P}<0.01)$.

Table 4 shows that beef storability has a very significant $(P<0.01)$ effect on the organoleptic value of beef flavor. Based on this research, it can be answered that the storability of beef has a very significant effect on the value of organoleptic flavor of beef.

\section{Conclusion}

Soaking beef with liquid smoke can preserve beef. The duration of 15 minutes liquid smoke soaking is the best in increasing the organoleptic value of the aroma of beef and the storability of beef greatly affects the value of cooking losses, tenderness values and organoleptic values (texture, aroma, and taste) for 3-4 weeks. 


\section{References}

[1] Aberle, E.D., J.C. Forrest, D.E. Gerrard, E.W. Mills, H.B. Hendrick, M.D. Judge,R.A. Merkel.2001. Principles of Meat Science. Edisi ke-4. Kendall/Hunt, Iowa.

[2] Abustam, E. Dan H. M. Ali. 2005. Dasar Teknologi Hasil Ternak. Buku Ajar. Program A2 Jurusan Produksi Ternak Fakultas Peternakan Universitas Hasanuddin, Makasar.

[3] Abustam, E. 2009. Konversi Otot Menjadi Daging. www//:http/konversi-otot-menjadi-daging.html Diakses tanggal 10 September 2015

[4] Adawyah, R. 2007. Pengolahan dan Pengawetan Ikan. Jakarta : PT. Bumi Aksara.

[5] Astawan, Made. 2008a. Khasiat Makanan Mentah. Jakarta: PT. GramediaPustaka Utama

[6] Bouton, P. E., P. V. Harris dan W. R. Shorthose. 1975. J. Tech. Stud 6,297.

[7] Harjono, M. 2008. Ilmu dan Teknologi Daging. www//:http./ilmu-dan-teknologidaging.html.

[8] Lawrie, R. A., 1995. Ilmu Daging. Edisi Kelima, Penerjemah AminuddinParakasi,UI Press, Jakarta.

[9] Lawrie, R. A. 2003. Meat science.Edisi Ke-5. Penerjemah: A.Perakasi. UI press.Jakarta. 